\title{
Role of Structural Change in Economic Growth: An Empirical Evidence from a Panel of Asian Countries
}

\author{
Umar Riaz, Babar Hussain* \& Arshad Ali Bhatti \\ International Institute of Islamic Economics, International Islamic University, Islamabad, Pakistan. \\ Received: September 06, 2020 \\ Published Online: December 31, 2020
}

\begin{abstract}
Economic growth, although being a major quest of all the economies, is not an automatic phenomenon. Among its determinants, structural change in the form of reallocation of labour from low to high productivity sectors is of crucial importance. In view of the remarkable growth performance and unprecedented structural change of Asia in the last couple of decades, this paper empirically investigated the case of 20 selected Asian countries. By employing the data spanning from 1991 to 2018, the study shows three main results. First, by employing Shift Share Analysis framework, it reaffirms the findings of previous literature that structural change contributes to the aggregate productivity growth. Second, by utilizing Generalized Methods of Moments technique, the results find it to be an important booster of growth. Third, the results are reliable and consistent with alternative measures of structural change like Norm of Absolute Values and Modified Lilien Index. Taken together, these findings suggest that the governments in Asia (other regions like Africa and Latin America may alike) must chalk out policies for structural change promotion.
\end{abstract}

Keywords: Structural Change, Economic Growth, Asian Countries, Panel Data Models, System GMM.

JEL Classification: L16; O47; O53; C23

\section{Introduction}

Economic growth has been a fundamental issue of economics since it started as a discipline. It is the desire of each country of the world to have high economic growth, but it cannot be considered as an automatic and spontaneous phenomenon. As large disparities exist in the economic performance across the countries, this has lured a burgeoning of investigation into the factors that determine these contrasting results in different countries (Opoku \& Yan, 2018). Among others, structural change is also one of the decisive factors of economic growth. The word 'structural change' or 'structural transformation ${ }^{1}$ is frequently used in economics, particularly in development literature. Being a particular facet of development, structural change retained its importance in development economics for quite a long time (Erumban et al., 2019). Page (2017) note that it was the main theme of the growth theories in the era of $1950 / 60$ 's. However, with the advent of neo-classical growth theories in 1980/90's, where the focus was on 'whole economy', the concept was overlooked. The author argued that their outlined prescriptions like physical and human capital, openness, institutions, and governance happened of little help to the policy makers. This rejuvenated the interest of economic theorists 
in the field of structural change at the finale of $20^{\text {th }}$ century (Arena, 2017).

Structural change has different aspects, and many uses in economics. According to Gabardo et al. (2017) broadly, structural change entails all the changes in production and employment within and between all sectors along with emergence of new sectors besides the exiting of older ones, while narrowly, it is the compositional alterations in primary, secondary, and tertiary sectors of the economy. Van-Neuss (2019) defines structural change as the "reallocation of economic activity across the three broad sectors agriculture, manufacturing and services". The current study uses this conception of structural change and analyses its role in growth process. Over time, changes occur in the structure of the economies as they make progress (Olczyk \& Kordalska, 2018). According to Briones and Felipe (2013) Asia has gained rapid structural transformation in the past several decades and this has attracted enormous interest in its future development. They anticipate that in the next few decades, Asia will become an economic giant eclipsing Europe and Northern America. The list of economy wide factors for its growth sustainability include among others, manufacturing, and services but not agriculture. The reason for exclusion of agriculture is its slower growth relative to other sectors and its falling share in output. According to Aizenman et al. (2012) the unprecedented structural change in both scale and speed, in Asian economies, is also due to the rapid and sustained economic growth. They also claimed that Asian economies witnessed structural change in shorter period relative to advanced countries of the world.

The following Figure 1 and 2 depict these facts accordingly. The figures show the average share of the agriculture, industry, and services, in terms of employment and value added respectively, are shown for six sub-periods. These figures show that the share of agriculture (services) in terms of both employment and value-added decreases (increases) for all the subperiods. The industry share in employment increases for all the sub-periods but its pattern shows slight variability in case of its value-added share i.e.; it decreases for some periods while increases for others.

Figure 1: Sectoral 5 years average employment (in \% of total employment)

Sectoral 5 years average employment (in \% of total employment)

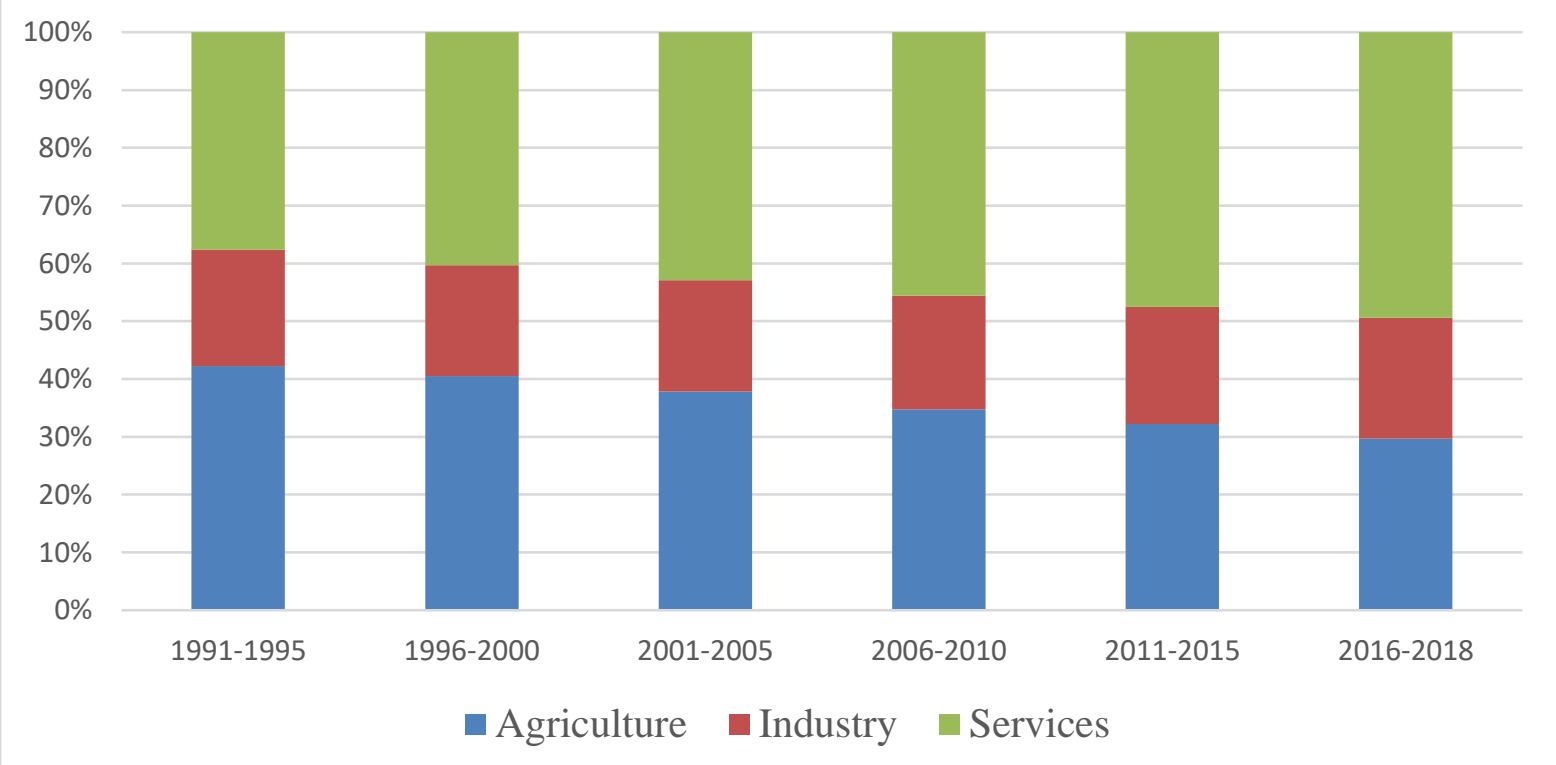

Source: Data is from World Development Indicators (WDI) 
Figure 2: Sectoral 5 years average Value Added (in \% of total GDP)

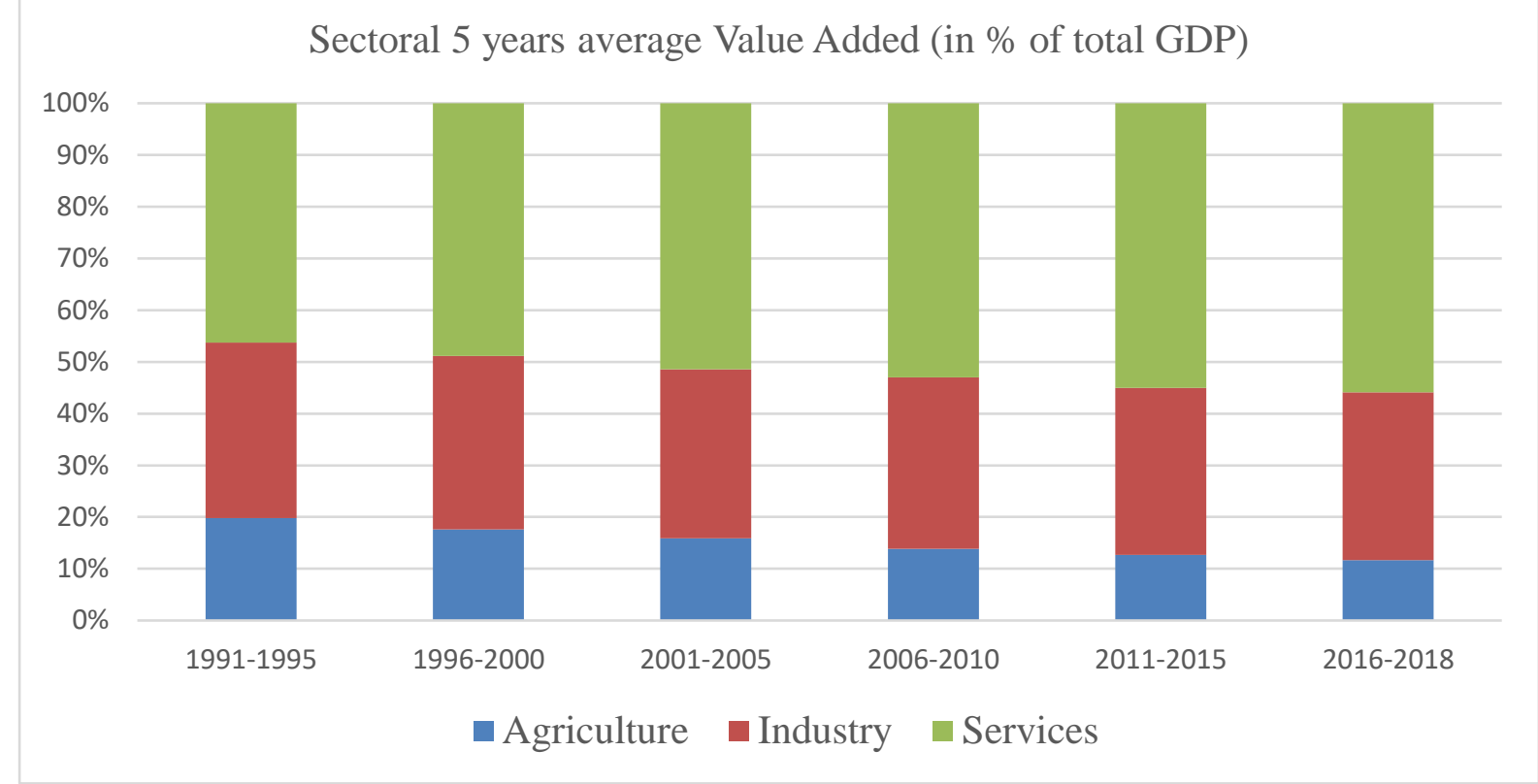

Source: Data is from World Development Indicators (WDI)

It is clear from the above figures that labour has been moved from agriculture towards industry and services sector in the sample period. Moreover, McMillan et al. (2014) found that structural change enhances labour productivity only in case of Asia as compared to Latin America and Africa, and hence created enormous potential for growth. Therefore, to provide empirical insights to the above thesis, present research endeavours to demonstrate the growth effects of this change in Asian countries. This region has diverse economic structures where some countries, like East Asian, have gained the status of industrialized countries while South Asian and Central Asian countries are mostly agricultural, particularly in employment. Results of the study will be surely helpful for the policy makers to decide about structures of their economies and devise meaningful strategies for the economic uplift. In view of the above discussion, the present study augments the existing literature in three ways: i) for empirical purpose, the study followed system GMM methodology that is used for tackling endogeneity problem; ii) the study takes alternative measures of structural change to ascertain the results robustness, and iii) the study draws policy recommendations based on the empirical findings.

The paper is structured as follows. After introduction in Section one, Section two of the paper offers the relevant literature. Section three is reserved for methodology. The results along with their interpretations are reported in section four. The last section draws upon conclusions and relevant policy recommendations.

\section{Theoretical Approach}

In the debate on agenda items of economic growth and productivity, the centre-stage has always been occupied by the concept of structural change (Erumban et al., 2019). Clark (1951) recognized the idea that as economies develop, the share of agriculture, both in output and employment, would decline and that of industry would rise first and then fall in favour of services, was put forward long ago by Sir William Petty in $17^{\text {th }}$ century. However, despite its high significance for growth and labour, the advent of neo classical growth theorists overlooked it. According to Krüger (2008) this can be evident from the fact that there is paucity of general 
theory of structural change up till now, but various theoretical approaches do exist that are related with the complexities of structural change in the economy.

More recently, Gabardo et al. (2017) have an extensive survey of different school of thought that theorize and model structural change into the growth analysis. They noted that although it has been discussed by many authors, among pioneers are Fisher (1939), Clark (1951), Kuznets (1957) and Chenery (1960). ${ }^{2}$ However, most of these early efforts were mainly empirical in nature. The authors argue that despite having an important role in empirical growth process, yet it has not been fully merged into the growth analysis. They put forward two reasons for this failure. The first reason is, the early growth models are mainly based on aggregate variables while for structural change analysis, multi sector models are necessary. The second reason is, for quiet long-time growth was analysed from the supply side like technological progress, while leaving aside the demand side like consumption evolution analysis, having vital importance for structural change analysis.

After the World War-II devastations, many newly independent states arose on the globe, and for their economic growth promotion, the growth theory (exogenous as well as endogenous) was at the central position in modern economics (Gabardo et al., 2017). These models are prominently aggregated and not suited for analysing the peculiarities of structural change. Because of their minimalist structure and simplicity, these models are used by all spheres of economists in finding growth determinants and their effects. However, Gabardo et al., (2017) argue that their assumption of symmetric industries (all industries growing evenly) make them inappropriate for analysing the process of structural changes. Therefore, by the dawn of 1950s decade, some economists developed and put forward an alternative approach for growth analysis called dual economy model.

Lewis (1954) developed the first dual economy model. It was comprised of two sectors: traditional and modern. The former is supposed to have unlimited supply of labour, while the latter uses reproducible capital. The central viewpoint is the transfer of labour from the traditional agriculture sector to the modern capitalist sector. Due to unlimited availability of labour at the subsistence wage level, there are great prospects for the modern sector to expand. It means, there are more profits for the capitalists, which will be re-ploughed in the modern sector. This will demand and absorb more labour being transferred from the traditional sector and increase and sustain the capital accumulation in modern sector over time. It means, the release of labour from the subsistence sector and more employment in modern sector leads to an output expansion.

According to Gabardo et al. (2017) although, dual economy models are the initial efforts in integrating structural change into the growth analysis and provide important insights about the structural change processes, however, these models are limited in scope as they cannot cover all the spheres of structural change mechanism. Also, their assumption about 'the presence of unlimited supply of labour in agriculture that will move towards industry' is not forever but eventually reaches a point where wages become equal in both sectors and this movement gets ceased. Hence, the dualistic structure of the economy ends and a neoclassical labour market is formed. Therefore, there was a need of comprehensive models that can take into consideration all the complexities relevant to structural change.

Along with the Lewis model, the works of Kuznets (1957), Kaldor (1961) and Chenery (1960) are also pronounced in the theoretical literature. Kuznets (1957) noted that structural change 
must be a fundamental part of modern economic growth. In his enlisted six attributes of describing the modern growth process, the third one is related to structural change. It states that structural change comprises the movement away from the primary to the secondary and, recently, away from the secondary to the tertiary sector. Kaldor (1967) also emphasized on the importance of economic structure for the development process. He argued that manufacturing sector is better suited for economic development than the other sectors of the economy as this sector has both static and dynamic increasing returns to scale. Due to these attributes of the manufacturing sector, he postulated that a country having faster growth rate of the secondary (manufacturing) sector, the faster will be its growth rate of GDP. McMillan et al. (2017) noted that investment only in fundamentals like human capital and institutions result only in steady and slow growth. For rapid and sustained growth, structural change is necessary along with high human capital and good institutions. Likewise, Rodrik (2014) argues that despite having low fundamental capabilities, poor countries can experience growth miracles and unconditional convergence with structural change in the form of industrialization.

\section{Empirical Review}

A variety of empirical studies exist that seek validation of the structural change nexus with productivity and growth. However, a concrete conclusion cannot be drawn yet as the literature provides mix results (Zulkhibri et al., 2015; Vu, 2017). For a better comprehension, the study follows Ahson et al. (2017) who categorized the literature into two types: one is decomposition methodology and second is regression-based studies. A study based on decomposition methodology decomposes aggregate productivity growth into changes due to within the sectors productivity growth (called within effects) and changes due to reallocation of labour across the sectors (called between effects or structural change effects). Most of the studies, for example McMillan et al. (2014), De-Vries et al. (2015), Padilla-Pérez and Villarreal (2017), Ahson et al. (2017) found within effect stronger than structural change effect in bringing changes in aggregate productivity. However, Hasan et al. (2013) and Nguyen (2018) observed varying contributions from the two components in the aggregate productivity growth.

The second strand of empirical literature, which is based on regression analysis. In this approach, structural change is measured from different methods including the decomposition method. Results from this group of studies are also mixed and inconclusive. For example, Dietrich (2012) and Cortuk \& Singh (2011) found causal link between structural transformation and growth while a recent study of Olczyk and Kordalska (2018) concluded that the relationship between the two is a heterogeneous process depending on the selected group of countries. Silva and Teixeira (2011) and Teixeira and Queirós (2016) have found significant positive impact of structural change on productivity growth in the context of Organization for Economic Co-operation and Development (OECD) countries. In case of African countries, Busse et al. (2019) have found its boosting effects while Carmignani and Mandeville (2014) have found retarding effects.

Mahmood and Linden (2017) analysed the relationship between the dynamics of agriculture, industry, and services with economic growth of the Schengen countries. They found that industrial growth rate is the major cause of increasing economic growth, agriculture has no role while services have a negative effect which supports the Baumol effect. Zulkhibri et al. (2015) found a long-run association between the two variables for their selected 5 emerging countries. Opoku and Yan (2018) found industrialization as an important booster of economic growth in African. In case of Asia, Vu (2017) and Ahson et al. (2017) found significant impact of 
structural change on economic growth. McMillan et al. (2014) found it growth accelerating in case of Asian countries while growth decelerating in case of Latin American and African countries. As, the empirical literature is inconclusive, hence prompting for more deep investigation of the nexus between growth and structural change.

\section{Research Methodology}

\subsection{Model Specification}

The prime objective of this study is to empirically examine if structural change has any impact on economic growth. In this connection, the model specified is broadly like others (e.g., Teixeira \& Queirós, 2016; and Opoku \& Yan, 2018). The model takes the form as follows:

$$
y_{i t}=\alpha y_{i t-1}+\beta_{1} S C_{i t}+\beta X_{i t}+\mu_{i}+\omega_{t}+\varepsilon_{i t}
$$

In the above expressions, subscripts like ' $i$ ' denotes the country $(i=1,2,3, \ldots, N)$ and ' $t$ ' denotes the time $(\mathrm{t}=1,2,3, \ldots, \mathrm{T}) . \mathrm{y}_{\mathrm{t}}$ and $\mathrm{y}_{\mathrm{t}-1}$ denotes current period per capita GDP and initial period per capita GDP respectively. SC stands for structural change which is our main variable. The symbol ' $\mathrm{X}$ ' is a matrix of control variables. Also, ' $\mu_{\mathrm{i}}$ ' and ' $\omega_{\mathrm{t}}$ ' is the country and period-specific effect respectively, and ' $\varepsilon_{\mathrm{it}}{ }^{\prime}$ is the usual error term. Alternatively, Eq. (1) can be written as follows:

Or

$$
\mathrm{y}_{\mathrm{it}}-\mathrm{y}_{\mathrm{it}-1}=\alpha \mathrm{y}_{\mathrm{it}-1}-\mathrm{y}_{\mathrm{it}-1}+\beta_{1} \mathrm{SC}_{\mathrm{it}}+\hat{\beta} \mathrm{X}_{\mathrm{it}}+\mu_{\mathrm{i}}+\omega_{\mathrm{t}}+\varepsilon_{\mathrm{it}}
$$

Or

$$
\text { Growth }=(\alpha-1) \mathrm{y}_{\mathrm{it}-1}+\beta_{1} \mathrm{SC}_{\mathrm{it}}+\dot{\beta} \mathrm{X}_{\mathrm{it}}+\mu_{\mathrm{i}}+\omega_{\mathrm{t}}+\varepsilon_{\mathrm{it}}
$$

$$
\text { Growth }=\beta_{0} y_{i t-1}+\beta_{1} S_{i t}+\dot{\beta} X_{i t}+\mu_{i}+\omega_{t}+\varepsilon_{i t}
$$

Where $\beta_{0}=\alpha-1$ is convergence coefficient. Eq. (4) is the baseline model for estimation.

\subsection{Estimation Techniques}

The researchers face the major problem of endogeneity in the estimation of economic growth models (Opoku \& Yan, 2018). In the present case, structural change can accelerate economic growth and vice-versa as elaborated by Dietrich (2012), Teixeira \& Queirós (2016) and Vu (2017). These problems render the traditional estimators like OLS, fixed effects and random effects biased and inconsistent. According to Opoku and Yan (2018) a prevalent method to handle the endogeneity problem is to use the instrumental variable technique. They noted that estimation through this technique can help in finding the causes of growth provided that the instruments specified have no direct effect on growth but only indirect effect via the endogenous variable. However, they added that this method is not free from limitations. This is because, most often the variables chosen as instruments have little power in explaining the endogenous variables (Bound et al., 1995). The regression estimates based on these instruments could be therefore inconsistence.

In recent decades, for addressing endogeneity and unobserved heterogeneity problem, the researchers have developed a technique called GMM, which utilizes own lags of the endogenous variables as instruments (Roodman, 2009). Therefore, the current study opted for 
GMM estimator as previous studies (e.g., Teixeira \& Queirós, 2016; Vu, 2017; Opoku \& Yan, 2018) also relied on similar research. GMM estimator has commonly two types: 'Difference GMM' and 'System GMM.' The difference GMM changes the equation into first differences to remove the country fixed effects. These 'differences' are then instrumented with the lagged values of the endogenous variables. The system GMM adds another equation to the difference GMM to get a system of two equations. One equation is in difference instrumented with lagged levels and the other is in levels instrumented with lagged differences. However, Bond et al. (2001) highlighted that difference GMM estimates may be prone to weak instruments problem particularly in case of small time series. Therefore, the present study preferred system GMM over difference GMM for empirical analysis. It has one step and two step estimation procedures. The study opted for the former as the standard errors of the latter are highly downward biased (Blundell \& Bond, 1998).

\subsection{Data}

The paper takes the case of 20 Asian countries over the period 1991 to 2018, entirely dictated by the availability of data regarding the variables; particularly structural change variable. Although, yearly data is available, this study preferred to use non-overlapping 5-year averages data. This is to reduce the sensitivity of the data to temporary factors related with the business cycle. Also, GMM estimators require greater sample size than the time (Opoku \& Yan, 2018). The dependent variable is economic growth calculated as the log difference of current and previous years GDP per capita multiplied by 100. In case of the explanatory variables, structural change is the core variable. For its measurement, this study employs the De-Vries et al. (2015) version of the Shift-Share-Analysis (SSA) method that has following form:

$$
\Delta \mathrm{P}=\sum_{\mathrm{i}}^{\mathrm{n}} \Delta \mathrm{p}_{\mathrm{i}} \mathrm{e}_{\mathrm{i} 0}+\sum_{\mathrm{i}}^{\mathrm{n}} \Delta \mathrm{e}_{\mathrm{i}} \mathrm{p}_{\mathrm{i} 0}+\sum_{\mathrm{i}}^{\mathrm{n}} \Delta \mathrm{p}_{\mathrm{i}} \Delta \mathrm{e}_{\mathrm{i}}
$$

Where $P$ is the aggregate labour productivity equal to total value added divided by total number of employed labour force. $i$ Denotes the number of sectors. $p_{i}$ is the sectoral labour productivity equal to the value added divided by the labour employed in that sector. $e$ is the employment share of the sector in total employment. $\Delta$ Shows the change between current and previous periods. The sectoral value-added data are taken from World Development Indicators (WDI), while the corresponding sectoral employment data are taken from International Labour Organization (ILO). Following Micmillan et al. (2017), Ahson et al. (2017) and Timmer and Szirmai (2000), the second and third term of the equation (5) are added to get the structural change variable. As motivated by the previous empirical literature, the model has a bunch of control variables. This includes domestic investment (gross fixed capital formation as a percentage of GDP), government expenditure (general government final consumption expenditure as a percentage of GDP), trade openness (exports plus imports as a percentage of GDP), population growth (annual \%), and inflation (GDP deflator; annual \%). The data for GDP per capita and all the control variables are taken from WDI. The descriptive statistics are given in table-A2 in the appendix. All the variables are logged except population growth, and all monetary variables are in constant \$2010.

\section{Results and Discussion}

This section portrays the empirical results. The discussion is mainly in two folds. First the paper 
discusses growth of aggregate productivity along with the contributions of its different components. Second, the study discusses the regression results.

\subsection{Decomposition of Aggregate Productivity Growth}

Here, the description of the contribution of three different components/effects in the aggregate productivity growth is presented. The dynamics are set out in the table-1. The first row of the above table provides the details of the full sample period (1991-2018). It shows that on the average, aggregate productivity grows at the rate of 2.41 percent. In this growth, within effect has major contribution of 77.59 percent (1.87 percentage points). This reflects that improvement within each sector is the dominant source of aggregate productivity. The static effect contributes positively at 28.63 percent ( 0.69 percentage points). However, the dynamic effect is negative and contributes negatively by -6.22 percent $(-0.15$ percentage points). DeVries et al. (2015) call positive static effect and negative dynamic effect 'static gains' and 'dynamic losses.' These results are in the same fashion as McMillan et al. (2014) and De-Vries et al. (2015). These are in concordance with the findings of McMillan et al. (2014). They found that Asia's productivity growth experience is different from Africa and Latin America. This is mainly because the Asia's productivity growth was all due to both within effect and structural change effect.

Table 1: Decomposition of aggregate labour productivity growth rates

\begin{tabular}{lccccccc}
\hline Years & $\begin{array}{c}\text { Total } \\
\text { Productivity }\end{array}$ & $\begin{array}{c}\text { Within } \\
\text { Effect }\end{array}$ & $\%$ & $\begin{array}{c}\text { Static } \\
\text { Effect }\end{array}$ & $\%$ & $\begin{array}{c}\text { Dynamic } \\
\text { Effect }\end{array}$ & $\%$ \\
\hline $1991-2018$ & 2.41 & 1.87 & 77.59 & 0.69 & 28.63 & -0.15 & -6.22 \\
\hline $1991-1995$ & 0.85 & 0.15 & 17.64 & 0.72 & 84.71 & -0.02 & -2.35 \\
\hline $1996-2000$ & 1.98 & 1.97 & 99.52 & 0.28 & 13.87 & -0.27 & -13.39 \\
\hline $2001-2005$ & 3.31 & 2.42 & 73.04 & 1.18 & 35.53 & -0.28 & -8.58 \\
\hline $2006-2010$ & 4.00 & 3.47 & 86.62 & 0.6 & 15.01 & -0.07 & -1.63 \\
\hline $2011-2015$ & 3.09 & 2.43 & 78.71 & 0.78 & 25.22 & -0.12 & -3.93 \\
\hline $2016-2018$ & 3.26 & 2.89 & 88.70 & 0.52 & 16.00 & -0.15 & -4.7 \\
\hline
\end{tabular}

Notes: Author's calculations based on equation (5).

Next, the study considers different periods to see the aggregate productivity growth and its three components. Aggregate productivity grows from 0.85 in the period 1991-1995 to 4.00 in period 2001-2005 and then decreases in the periods afterwards. The contributions of different components across the periods are same like that full sample period, as within effect is stronger than the static and dynamic effects. However, a greater variability can be observed in their magnitudes of contributions. For example, within effect contribution ranges in 17.64 to 99.52 percent, static effect ranges in 13.87 to 84.71 and dynamic effect ranges in -0.02 to -0.28 across different periods. It can therefore be established that along with the within effect, structural change effect also plays a key role in the sampled countries productivity growth.

\subsection{Association between Structural Change and Economic Growth}

This sub-section discloses and explains the empirical association between the variables. For this purpose, taking into considerations the recent relevant studies like; Opoku and Yan (2018) and Carraro and Karfakis (2018) the study uses two estimators-fixed effect and system GMM estimator for equation (4). The GMM results are considered more robust and reliable and fixed 
effect estimates provide the useful benchmarks. Note that in applying both the estimators, the heteroscedasticity and autocorrelation problem of the standard errors by was fixed by including 'robust' in the Stata command. Fixed effects results are shown in table-A3 in the Appendix. We start by estimating a simple model in which only initial GDP per capita is used as a regressor and then added the selected explanatory variables one by one. Hence, there are 7 models. In most of the models, the main variable-structural change is positive and statistically significant. However, as pointed out by Caselli et al. (1996) fixed effect estimator produces biased standard least square estimates in dynamic panel models. Also, in the absence of strictly exogeneity in the explanatory variables, fixed effect model results are more prone to biasness (Opoku \& Yan, 2018). Therefore, recourse is made to GMM estimator, which caters mostly for above mentioned problems.

Table 2: Structural Change and Economic Growth (System GMM)

\begin{tabular}{|c|c|c|c|c|c|c|c|}
\hline Variables & $(1)$ & $(2)$ & (3) & $(4)$ & $(5)$ & $(6)$ & $(7)$ \\
\hline LGDPPC & $\begin{array}{c}-0.689 * * \\
(0.274)\end{array}$ & $\begin{array}{c}-1.189 * * * \\
(0.402)\end{array}$ & $\begin{array}{c}-1.213^{* * *} \\
(0.422)\end{array}$ & $\begin{array}{c}-1.032 * * \\
(0.399)\end{array}$ & $\begin{array}{c}-0.987 * * \\
(0.381)\end{array}$ & $\begin{array}{c}-0.970 * * \\
(0.367)\end{array}$ & $\begin{array}{l}-1.302 * \\
(0.628)\end{array}$ \\
\hline SCssa & & $\begin{array}{c}0.695^{* *} \\
(0.272)\end{array}$ & $\begin{array}{l}0.516^{*} \\
(0.279)\end{array}$ & $\begin{array}{l}0.501^{*} \\
(0.277)\end{array}$ & $\begin{array}{c}0.470 \\
(0.299)\end{array}$ & $\begin{array}{l}0.527 * \\
(0.303)\end{array}$ & $\begin{array}{l}0.694^{*} \\
(0.369)\end{array}$ \\
\hline $\begin{array}{l}\text { Dom. } \\
\text { Invest. }\end{array}$ & & & $\begin{array}{c}4.475 * * \\
(1.891)\end{array}$ & $\begin{array}{c}4.756^{* *} \\
(1.719)\end{array}$ & $\begin{array}{c}4.874 * * \\
(1.743)\end{array}$ & $\begin{array}{c}4.327 * * \\
(1.626)\end{array}$ & $\begin{array}{l}4.904 * * \\
(1.923)\end{array}$ \\
\hline $\begin{array}{l}\text { Govt. } \\
\text { Expend. }\end{array}$ & & & & $\begin{array}{c}-4.096 * * \\
(1.687)\end{array}$ & $\begin{array}{l}-3.941 * \\
(2.047)\end{array}$ & $\begin{array}{l}-3.955^{*} \\
(2.024)\end{array}$ & $\begin{array}{l}-5.256^{*} \\
(2.613)\end{array}$ \\
\hline Openness & & & & & $\begin{array}{l}-0.170 \\
(0.546)\end{array}$ & $\begin{array}{l}-0.230 \\
(0.474)\end{array}$ & $\begin{array}{l}-0.375 \\
(0.947)\end{array}$ \\
\hline $\begin{array}{l}\text { Pop. } \\
\text { Growth }\end{array}$ & & & & & & $\begin{array}{l}-0.224 \\
(0.340) \\
\end{array}$ & $\begin{array}{c}-2.615 * * \\
(1.215)\end{array}$ \\
\hline Inflation & & & & & & & $\begin{array}{c}0.847 \\
(1.065) \\
\end{array}$ \\
\hline Constant & $\begin{array}{l}-4.436 \\
(3.123)\end{array}$ & $\begin{array}{c}-10.802 * * \\
(4.615)\end{array}$ & $\begin{array}{c}-24.663 * * \\
(8.724)\end{array}$ & $\begin{array}{c}-14.297 * \\
(6.874)\end{array}$ & $\begin{array}{c}-13.860 * \\
(7.098)\end{array}$ & $\begin{array}{c}-11.641 * \\
(6.665)\end{array}$ & $\begin{array}{c}-11.380 * \\
(6.168)\end{array}$ \\
\hline $\begin{array}{l}\text { No. of } \\
\text { Observation }\end{array}$ & 120 & 120 & 120 & 120 & 119 & 119 & 119 \\
\hline $\begin{array}{l}\text { No. of } \\
\text { Groups }\end{array}$ & 20 & 20 & 20 & 20 & 20 & 20 & 20 \\
\hline $\begin{array}{l}\text { No. of } \\
\text { Instruments }\end{array}$ & 13 & 10 & 18 & 19 & 13 & 17 & 17 \\
\hline \multicolumn{8}{|c|}{ Diagnostics Tests (p-values) } \\
\hline $\operatorname{AR}(2)$ & 0.234 & 0.244 & 0.120 & 0.118 & 0.120 & 0.117 & 0.138 \\
\hline $\begin{array}{l}\text { Hansen J- } \\
\text { test }\end{array}$ & 0.169 & 0.292 & 0.200 & 0.245 & 0.259 & 0.160 & 0.171 \\
\hline
\end{tabular}

Notes: LGDPPC is lag of the GDP per capita, SCssa is structural change measured by SSA method, Dom. Invest.is domestic investment, Govt. Expend. is government expenditure, Openness is trade openness, Pop. Growth is population growth and Inflation is inflation rate. Time dummies are part of each model estimation but are not reported so as to conserve space. $*, * *, * * *$ denote significance at $10 \%, 5 \%$ and $1 \%$ respectively. The robust standard errors are given in the parentheses.

The estimates of the equation (4) via system GMM are reported in the table-2 above. Before going to explanation of the results, it is prudent to meet the two conditions. First is, the error 
terms should be free of $2^{\text {nd }}$ order autocorrelation, and second, the instruments must be valid. For this, the AR (2) test and Hansen test are used respectively. In all the models, both the conditions are satisfied and hence the results can be satisfactory and reliable. Like the fixed effect estimations, the GMM estimation is also carried out for 7 models starting from a simple model with only lag of GDP per capita as a regressor and then adding one by one all the control variables. Our core variable-structural change happens significantly positive in all models except model-5 where it turns out insignificant. This entails that the structural change has a potential boosting growth effect. This result validates the theories of Lewis (1954), Kuznets (1957), Kaldor (1961), and Chenery (1960). This result is also in concordance with many empirical studies, particularly in the case of Asian countries, like VU (2017), Ahson et al. (2017) and McMillan et al. (2014).

Most of the selected control variables happen out with their anticipated theoretical signs and significance. The lag of GDP per capita was found negative and significant across all models, showing conditional convergence among the countries (Zulfiqar \& Ain, 2018). The investment/physical capital formation variable as anticipated turned out significantly positive. This also validates the findings of the seminal studies like Barro (1991). The relationship of consumption on the part of governments and economic growth is uncertain and disputable in the literature (Nyasha \& Odhiambo, 2019). In the present case, it turned out negative. This supports the beliefs that it has catastrophic consequences for the economic growth as they bring inefficiencies, distortions and crowding out effects. The trade openness variable turned out insignificant. A relatively recent study of Keho (2017) shows that growth effects of trade openness are mixed, depending on the sampled countries, data set, its span and methodology. Therefore, this result may not be considered susceptible as this study is based on heterogeneous group of the sampled countries. Population growth impact is found negative and significant thus supporting the previous literature. This may be attributed to its dampening effect on the capital-labour ratio, which then reduces growth (Teixeira \& Queirós, 2016). Finally, an inflation is found positive but insignificant. This result is against the priori expectation as high prices are considered having negative effects on the economic growth.

\subsection{Robustness Checks}

This sub-section shows how robust results of the study are. To this end, the study employs two alternative proxies of structural change: Norm of Absolute Values (NAV) and Modified Lilien Index (MLI). These two indices are also used in this area by researchers like Dietrich (2012), Olczyk and Kordalska (2018), and Cortuk and Singh (2011). The NAV index, also named Michaely Index (1962) in the literature, is the most important and simple index of measuring structural change. It can take the form as:

$$
\mathrm{NAV}=\frac{1}{2} \sum_{\mathrm{i}=1}^{\mathrm{n}}\left|\mathrm{x}_{\mathrm{it}}-\mathrm{x}_{\mathrm{is}}\right|, \mathrm{t}=2, \ldots, \mathrm{T}, \mathrm{s}=1, \ldots, \mathrm{T}-1
$$

Where ' $x$ ' is the share of employment in sector ' $i$ ' in period ' $t$ ' and ' $s$.' It can be computed by taking the difference of the sector share in the two periods. Then these differences are summed up after taking their absolute values. Lastly, two divides these values as each change are made twice. NAV index can have a value from zero to unity. The value zero means that the sectorial shares remain constant, while unity means an occurrence of complete change in the economy. MLI is the modified version of Lilien index (1982) and can take the form as: 


$$
M L I=\sqrt{\sum_{i=1}^{n} x_{i, s} \cdot x_{i, t} \cdot\left(\ln \frac{x_{i, t}}{x_{i, s}}\right)^{2}}, x_{i, s}>0, x_{i, t}>0
$$

The notations used in MLI are in the same meaning as of NAV. A low MLI means slow rate while high MLI implies rapid rate of the structural change. The study re-estimates the model by using NAV and MLI indices of structural change. The results are reported in table-A3 in Appendix. The results are found akin to the previous measure of structural change by SSA method. This means that growth effect of structural change is robust to its different measures.

\section{Conclusion}

Among others, structural change remains one of the important boosters of growth in different countries and regions and hence Asia has no exception. Structural change is the "reallocation of economic activity across the three broad sectors agriculture, manufacturing and services" (Van-Neuss, 2019) and has been a prominent feature of economic growth ( $\mathrm{Vu}, 2017)$. Once an important concept of development economics theories in 1960s e.g.; Lewis (1954), Kuznets (1957), Kaldor (1961) and Chenery (1960) however, its importance waned 1980/90s due to the emergence of new growth theories and institutional economics. Nevertheless, the prescriptions like physical and human capital, openness, institutions, and governance etc; outlined by these growth theories proved to be of little practical relevance to public policy (Page, 2017). This rejuvenated the interest of economic theorists in the field of structural change at the finale of twentieth century (Arena, 2017).

This paper provides an empirical validation to the role of structural change in the process of economic growth in case of 20 selected countries in Asia. This has become imperative as this region has an unprecedented structural change in the form of shift from agriculture to manufacturing and to services, and witnessed it in shorter period relative to advanced countries of the world. By employing the data spanning from 1991-2018, the study shows three main results. First, by employing shift share analysis method, it reaffirms the previous literature findings that structural change positively contributes to the aggregate productivity growth. Second, by utilizing Generalized Methods of Moments (GMM) technique, the study ascertained that it is an important booster of growth in the selected countries. Third, the results are reliable and consistent to alternative measures of structural change. Therefore, for economic uplifts, the findings suggest reforms for structural change.

The findings of the study portray some important policy suggestions. The policy makers in Asia (and other regions like Africa and Latin America may alike) must chalk out policies for structural change promotion. A very prudent policy in this regard may be an industrialization and tertiarization as no country in the world except Australia, New Zealand and Canada have made progress based on agriculture (Opoku \& Yan, 2018). A smooth economic ground should be provided for the coordination between public and private sectors to move the economy towards higher productivity sectors. To this end, providing better infrastructure and financial facilities, improving human capital and institutions, and openness of the economy should be enlisted in the policy makers' prescriptions list (Opoku \& Yan, 2018; Carraro \& Karfakis, 2018). Finally, if the data allows, the study can be improved by taking more disaggregated sectors of the economy. Also, comparison can be made among different regions of the world like Asia, Africa, Latin America, and OECD countries. 


\section{References}

Ahson, U., Siddiqi, M. W., \& Mirza, F. (2017). Structural change and economic progress: Empirical evidence from selected Asian countries. Pakistan Journal of Social Sciences, $37(2)$, http://pjss.bzu.edu.pk/website/journal/article/5ec615142b5c1/page

Aizenman, J., Lee, M., \& Park, D. (2012). The relationship between structural change and inequality: a conceptual overview with special reference to developing Asia. Asian Development Bank. https://www.adb.org/sites/default/files/publication/156251/adbiwp396.pdf

Arellano, M., \& Bond, S. (1991). Some tests of specification for panel data: Monte Carlo evidence and an application to employment equations. The review of economic studies, 58(2), 277-297. http://dx.doi.org/10.2139/ssrn.2175383

Arellano, M., \& Bond, S. (1991). Some tests of specification for panel data: Monte Carlo evidence and an application to employment equations. The Review of Economic Studies, 58(2), 277. https://doi.org/10.2307/2297968

Arena, R. (2017). Modern structural economic dynamics in the short and the long run. Journal of the History of Economic Thought, 39(1), 101-123. https://doi.org/10.1017/s105383721600105x

Barro, R. J. (1991). Economic growth in a cross section of countries. The Quarterly Journal of Economics, 106(2), 407. https://doi.org/10.2307/2937943

Blundell, R., \& Bond, S. (1998). Initial conditions and moment restrictions in dynamic panel data models. Journal of Econometrics, 87(1), 115-143. https://doi.org/10.1016/s0304-4076(98)00009-8

Bond, S. R., Hoeffler, A., \& Temple, J. (2001). GMM estimation of empirical growth models (No. 3048). CEPR Discussion Papers. https://ssrn.com/abstract=290522

Bound, J., Jaeger, D. A., \& Baker, R. M. (1995). Problems with instrumental variables estimation when the correlation between the instruments and the endogenous explanatory variable is weak. Journal of the American Statistical Association, 90(430), 443-450. https://doi.org/10.1080/01621459.1995.10476536

Briones, R., \& Felipe, J. (2013). Agriculture and structural transformation in developing Asia: review and outlook. Asian Development Bank Economics Working Paper Series No. 363. https://doi.org/10.2139/ssrn.2321525

Busse, M., Erdogan, C., \& Mühlen, H. (2019). Structural transformation and its relevance for economic growth in Sub-Saharan Africa. Review of Development Economics, 23(1), 33-53. https://doi.org/10.1111/rode.12543

Carmignani, F., \& Mandeville, T. (2014). Never been industrialized: a tale of African structural change. Structural Change and Economic Dynamics, 31, 124-137. https://doi.org/10.1016/j.strueco.2014.09.002

Carraro, A. \& Karfakis, P. (2018). Institutions, economic freedom, and structural transformation in 11 sub-Saharan African countries. FAO Agricultural Development Economics Working Paper 18-01. Rome, FAO. http://www.fao.org/publications/card/es/c/I8422EN/

Caselli, F., Esquivel, G., \& Lefort, F. (1996). Reopening the convergence debate: a new look at cross-country growth empirics. Journal of Economic Growth, 1(3), 363-389. https://doi.org/10.1007/bf00141044

Chenery, H. (1960). Patterns of industrial growth. The American Economic Review, 50(4), 624654. http://www.jstor.org/stable/1812463

Clark, C. (1951). The conditions of economic progress. MacMillan. 
Cortuk, O., \& Singh, N. (2011). Structural change and growth in India. Economics Letters, 110(3), 178-181. https://doi.org/10.1016/j.econlet.2010.11.034

De-Vries, G., Timmer, M., \& de-Vries, K. (2015). Structural transformation in Africa: static gains, dynamic losses. The Journal of Development Studies, 51(6), 674-688. https://doi.org/10.1080/00220388.2014.997222

Dietrich, A. (2012). Does growth cause structural change, or is it the other way around? A dynamic panel data analysis for seven OECD countries. Empirical Economics, 43(3), 915-944. https://doi.org/10.1007/s00181-011-0510-z

Erumban, A. A., Das, D. K., Aggarwal, S., \& Das, P. C. (2019). Structural change and economic growth in India. Structural Change and Economic Dynamics, 51, 186-202. https://doi.org/10.1016/j.strueco.2019.07.006

Fisher, A. G. (1939). Production, primary, secondary, and tertiary. Economic Record, 15(1), 24-38. https://doi.org/10.1111/j.1475-4932.1939.tb01015.x

Gabardo, F. A., Pereima, J. B., \& Einloft, P. (2017). The incorporation of structural change into growth theory: A historical appraisal. Economia, 18(3), 392-410. https://doi.org/10.1016/j.econ.2017.05.003

Hasan R., Lamba, S., \& Sen Gupta, A. (2013). Growth, structural change, and poverty reduction: evidence from India. ADB South Asia Working paper Series, No. 22. http://hdl.handle.net/11540/2060

Kaldor, N. (1961). Capital accumulation and economic growth. In The theory of capital (pp. 177-222). Palgrave Macmillan. https://doi.org/10.1007/978-1-349-08452-4_10

Kaldor, N. (1967). Strategic factors in economic development. Cornel University.

Keho, Y. (2017). The impact of trade openness on economic growth: the case of Cote d'Ivoire. $\begin{array}{llll}\text { Cogent Economics } \& \text { Finance, } & \text { 5(1). }\end{array}$ https://doi.org/10.1080/23322039.2017.1332820

Kruger, J. J. (2008). Productivity and structural change: a review of the literature. Journal of Economic Surveys, 22(2), 330-363. https://doi.org/10.1111/j.14676419.2007.00539.x

Kuznets, S. (1957). Quantitative aspects of the economic growth of nations: II. Industrial distribution of national product and labour force. Economic Development and Cultural Change, 5(S4), 1-111. https://doi.org/10.1086/449740

Lewis, W. A. (1954). Economic development with unlimited supplies of labour. The Manchester School, 22(2), 139-191. https://doi.org/10.1111/j.14679957.1954.tb00021.x

Lilien, D. M. (1982). Sectoral shifts and cyclical unemployment. Journal of Political Economy, 90(4), 777-793. https://doi.org/10.1086/261088

Mahmood, T., \& Linden, M. (2017). Structural change and economic growth in Schengen region. International Journal of Economics and Financial Issues, 7(1), 303-311. https://www.econjournals.com/index.php/ijefi/article/view/3547/pdf

McMillan, M., Rodrik, D., \& Sepulveda, C. (2017). Structural change, fundamentals, and growth: a framework and case studies. National Bureau of Economic Research. (No. w23378). https://ssrn.com/abstract=2964674

McMillan, M., Rodrik, D., and Verduzco-Gallo, I. (2014). Globalization, structural change, and productivity growth, with an update on Africa. World Development, 63, 11-32. https://doi.org/10.1016/j.worlddev.2013.10.012

Michaely, M. (1962). Concentration in the international trade (28). The North Holland Publishing.

Nguyen, H.C. (2018). Empirical evidence of structural change: the case of Vietnam's economic 
growth. Journal of Southeast Asian Economies, 35(2), 237-256. https://doi.org/10.1355/ae35-2h

Nyasha, S., \& Odhiambo, N. M. (2019). Government size and economic growth: a review of international literature. SAGE Open, https://doi.org/10.1177/2158244019877200

Olczyk, M., \& Kordalska, A. (2018). Growth and structural changes in transition countries: the chicken or the egg? Journal of Business Economics and Management, 19(3), 544565. https://doi.org/10.3846/jbem.2018.6580

Opoku, E. E. O., \& Yan, I. K. M. (2018). Industrialization as driver of sustainable economic growth in Africa. The Journal of International Trade \& Economic Development, 127. https://doi.org/10.1080/09638199.2018.1483416

Padilla-Pérez, R., \& Villarreal, F. G. (2017). Structural change and productivity growth in Mexico, 1990-2014. Structural Change and Economic Dynamics, 41, 53-63. https://doi.org/10.1016/j.strueco.2017.02.002

Page, J. (2017). Structural transformation: it's not just manufacturing anymore. The Brookings Institution, G-24 Technical Working Group. https://www.g24.org/wpcontent/uploads/2017/04/1.-Page-Structural-Transformation-It\%E2\%80\%99s-NotJust-Manufacturing-Anymore.pdf

Rodrik, D. (2014). the past, present, and future of economic growth. Challenge, 57(3), 5-39. https://doi.org/10.2753/0577-5132570301

Roodman, D. (2009). How to do Xtabond2: an introduction to difference and system GMM in Stata. The Stata Journal: Promoting Communications on Statistics and Stata, 9(1), 86-136. https://doi.org/10.1177/1536867x0900900106

Silva, E. G., \& Teixeira, A. A. (2011). Does structure influence growth? a panel data econometric assessment of "relatively less developed" countries, 1979-2003. Industrial and Corporate Change, 20(2), 457-510. https://doi.org/10.1093/icc/dtr003

Teixeira, A. A., \& Queiros, A. S. (2016). Economic growth, human capital, and structural change: a dynamic panel data analysis. Research Policy, 45(8), 1636-1648. https://doi.org/10.1016/j.respol.2016.04.006

Timmer, M. P., \& Szirmai, A. (2000). Productivity growth in Asian manufacturing: the structural bonus hypothesis examined. Structural Change and Economic Dynamics, 11(4), 371-392. https://doi.org/10.1016/s0954-349x(00)00023-0

Van-Neuss, L. (2019). The drivers of structural change. Journal of Economic Surveys, 33(1), 309-349. https://doi.org/10.1111/joes.12266

Vu, K. M. (2017). Structural change and economic growth: empirical evidence and policy insights from Asian economies. Structural Change and Economic Dynamics, 41, 6477. https://doi.org/10.1016/j.strueco.2017.04.002

Zulfiqar, K. \& Ain, Q. (2018). An analysis of income convergence across Asian countries. Forman Journal of Economic Studies, 14, 125-141. https://doi.org/10.32368/fjes.20181406.

Zulkhibri, M., Naiya, I., \& Ghazal, R. (2015). Structural change and economic growth in selected emerging economies. International Journal of Development Issues, 14(2), 98-116. https://doi.org/10.1108/ijdi-09-2014-0064 


\section{Appendices}

Table A1: List of Sampled Countries

\begin{tabular}{llll}
\hline Azerbaijan & Indonesia & Malaysia & Sri Lanka \\
\hline Bangladesh & Japan & Nepal & Tajikistan \\
\hline Bhutan & Kazakhstan & Pakistan & Thailand \\
\hline Hong Kong & Korea, Rep. & Philippines & Uzbekistan \\
\hline India & Kyrgyzstan & Singapore & Vietnam \\
\hline
\end{tabular}

Table A2: Summary Statistics and Correlation Matrix

\begin{tabular}{lcccccccc}
\hline & Growth & LGDPPC & SCssa & $\begin{array}{l}\text { Dom. } \\
\text { Invest. }\end{array}$ & $\begin{array}{l}\text { Govt. } \\
\text { Expend. }\end{array}$ & Openness & $\begin{array}{l}\text { Pop. } \\
\text { Growth }\end{array}$ & Inflation \\
\hline Panel A: Summary Statistic & & & & & & & \\
\hline Obs & 120 & 120 & 120 & 120 & 120 & 119 & 120 & 120 \\
\hline Mean & 3.015 & -5.867 & 4.747 & 3.230 & 2.437 & 4.369 & 1.303 & 2.011 \\
\hline Std. Dev. & 4.240 & 1.427 & 1.524 & 0.284 & 0.355 & 0.718 & 0.768 & 1.162 \\
\hline Min & -23.132 & -7.910 & 1.574 & 2.282 & 1.553 & 2.828 & -1.090 & -1.060 \\
\hline Max & 15.472 & -2.905 & 7.881 & 4.026 & 3.537 & 6.019 & 3.272 & 6.206 \\
\hline Panel B: Corr. Matrix & & & & & & & \\
\hline Growth & 1 & & & & & & & \\
\hline LGDPPC & -0.094 & 1 & & & & & & \\
\hline SCssa & 0.004 & 0.644 & 1 & & & & & \\
\hline Dom. Invest. & 0.310 & 0.190 & 0.318 & 1 & & & & \\
\hline Govt. Exp. & -0.231 & 0.193 & 0.182 & 0.130 & 1 & & & \\
\hline Openness & 0.010 & 0.392 & 0.522 & 0.100 & -0.021 & 1 & & \\
\hline Pop. Growth & 0.033 & -0.354 & -0.146 & -0.100 & -0.215 & 0.037 & 1 & \\
\hline Inflation & -0.431 & -0.322 & -0.153 & -0.210 & 0.072 & 0.145 & 0.051 & 1 \\
\hline Notes: Same as for table-2. & & & & & & & \\
& & & & & & & & \\
\hline
\end{tabular}

Notes: Same as for table-2.

Table A3. Structural Change and Economic Growth (Fixed Effect)

\begin{tabular}{|c|c|c|c|c|c|c|c|}
\hline Variables & (1) & (2) & (3) & (4) & (5) & (6) & (7) \\
\hline LGDPPC & $\begin{array}{c}-14.901 * * * \\
(2.671) \\
\end{array}$ & $\begin{array}{c}-15.338 * * * \\
(2.351) \\
\end{array}$ & $\begin{array}{c}-14.725 * * * \\
(2.471) \\
\end{array}$ & $\begin{array}{c}-14.181 * * * \\
(1.704) \\
\end{array}$ & $\begin{array}{c}-14.274 * * * \\
(1.539) \\
\end{array}$ & $\begin{array}{c}-14.378 * * * \\
(1.614) \\
\end{array}$ & $\begin{array}{c}-12.525 * * * \\
(1.445) \\
\end{array}$ \\
\hline SCssa & & $\begin{array}{c}0.919 * * \\
(0.323) \\
\end{array}$ & $\begin{array}{c}0.708^{* *} \\
(0.285) \\
\end{array}$ & $\begin{array}{c}0.414 \\
(0.354) \\
\end{array}$ & $\begin{array}{c}0.421 \\
(0.330) \\
\end{array}$ & $\begin{array}{c}0.413^{* *} \\
(0.321) \\
\end{array}$ & $\begin{array}{c}0.169^{* *} \\
(0.292) \\
\end{array}$ \\
\hline $\begin{array}{l}\text { Dom. } \\
\text { Invest. }\end{array}$ & & & $\begin{array}{c}4.395 * * * \\
(1.528) \\
\end{array}$ & $\begin{array}{c}4.519 * * * \\
(1.512) \\
\end{array}$ & $\begin{array}{c}4.453 * * * \\
(1.537) \\
\end{array}$ & $\begin{array}{c}4.140^{* * *} \\
(1.555) \\
\end{array}$ & $\begin{array}{c}4.252 * * \\
(1.787) \\
\end{array}$ \\
\hline Govt. Exp. & & & & $\begin{array}{c}-8.152 * * \\
(3.243) \\
\end{array}$ & $\begin{array}{c}-9.272 * * \\
(3.859) \\
\end{array}$ & $\begin{array}{c}-8.871 * * \\
(4.002) \\
\end{array}$ & $\begin{array}{c}-7.391 * * \\
(3.256) \\
\end{array}$ \\
\hline Openness & & & & & $\begin{array}{c}-0.847 \\
(1.431) \\
\end{array}$ & $\begin{array}{l}-0.670 \\
(1.494) \\
\end{array}$ & $\begin{array}{c}0.750 \\
(1.396) \\
\end{array}$ \\
\hline $\begin{array}{l}\text { Pop. } \\
\text { Growth }\end{array}$ & & & & & & $\begin{array}{c}0.455 \\
(0.409) \\
\end{array}$ & $\begin{array}{c}-0.273 \\
(0.409) \\
\end{array}$ \\
\hline Inflation & & & & & & & $\begin{array}{c}-1.641 * * * \\
(0.571)\end{array}$ \\
\hline Constant & $\begin{array}{c}-92.012 * * * \\
(17.061)\end{array}$ & $\begin{array}{c}-99.050 * * * \\
(14.035)\end{array}$ & $\begin{array}{c}-108.576 * * * \\
(14.634)\end{array}$ & $\begin{array}{c}-84.140 * * * \\
(13.206)\end{array}$ & $\begin{array}{c}-78.329 * * * \\
(15.545)\end{array}$ & $\begin{array}{c}-80.335 * * * \\
(17.157)\end{array}$ & $\begin{array}{c}-71.759 * * * \\
(15.747)\end{array}$ \\
\hline R-squared & 0.603 & 0.629 & 0.662 & 0.734 & 0.729 & 0.732 & 0.774 \\
\hline $\begin{array}{l}\text { \# of } \\
\text { Observ. }\end{array}$ & 120 & 120 & 120 & 120 & 119 & 119 & 119 \\
\hline \#of Group & 20 & 20 & 20 & 20 & 20 & 20 & 20 \\
\hline
\end{tabular}


Role of Structural Change in Economic Growth: An Empirical Evidence from a Panel . . .

Table A4: Structural Change and Economic Growth (System GMM)

\begin{tabular}{|c|c|c|}
\hline Variables & $(1)$ & $(2)$ \\
\hline LGDPPC & $\begin{array}{c}-1.452 * * * \\
(0.422)\end{array}$ & $\begin{array}{c}-1.449 * * * \\
(0.423)\end{array}$ \\
\hline SCnav & $\begin{array}{c}0.200^{* * *} \\
(0.337) \\
\end{array}$ & \\
\hline SCmli & & $\begin{array}{l}0.190 * * \\
(0.334)\end{array}$ \\
\hline Dom. Invest. & $\begin{array}{l}4.194 * \\
(2.085) \\
\end{array}$ & $\begin{array}{l}4.184 * \\
(2.083) \\
\end{array}$ \\
\hline Govt. Expend. & $\begin{array}{l}-1.514 \\
(1.439) \\
\end{array}$ & $\begin{array}{l}-1.515 \\
(1.438) \\
\end{array}$ \\
\hline Openness & $\begin{array}{l}1.284 * * \\
(0.537)\end{array}$ & $\begin{array}{l}1.287 * * \\
(0.536)\end{array}$ \\
\hline Pop. Growth & $\begin{array}{l}-0.607 \\
(0.605) \\
\end{array}$ & $\begin{array}{l}-0.607 \\
(0.606) \\
\end{array}$ \\
\hline Inflation & $\begin{array}{c}-1.558^{* *} \\
(0.570)\end{array}$ & $\begin{array}{c}-1.559^{* *} \\
(0.571)\end{array}$ \\
\hline Constant & $\begin{array}{c}-18.707 * * \\
(7.927)\end{array}$ & $\begin{array}{c}-18.564 * * \\
(7.875)\end{array}$ \\
\hline No.of Observations & 117 & 117 \\
\hline No. of Groups & 20 & 20 \\
\hline No.of Instruments & 19 & 19 \\
\hline \multicolumn{3}{|c|}{ Diagnostics Tests (p-values) } \\
\hline $\mathrm{AR}(2)$ & 0.353 & 0.353 \\
\hline Hansen J-test & 0.168 & 0.172 \\
\hline
\end{tabular}

Notes: Same as for table-2 except that SCnav and SCmli is structural change measured by NAV and MLI methods respectively.

\section{Notes:}

${ }^{1}$ On a terminological note, these two words are interchangeably used in this paper as used in the economics literature (Carraro \& Karfakis, 2018).

2 Only Clark (1951) among them identified productivity growth differences and Engel effects as two elements of sectoral resources shifts and hence laid the foundation for theory of structural change. 